\title{
Judah Benjamin: marginalized outsider or admitted insider?
}

Article

Accepted Version

MacMillan, C. (2015) Judah Benjamin: marginalized outsider or admitted insider? Journal of Law and Society, 42 (1). pp. 150-172. ISSN 0263-323X doi: https://doi.org/10.1111/j.14676478.2015.00702.x Available at https://centaur.reading.ac.uk/40108/

It is advisable to refer to the publisher's version if you intend to cite from the work. See Guidance on citing.

To link to this article DOI: http://dx.doi.org/10.1111/j.1467-6478.2015.00702.x

Publisher: Wiley-Blackwell

All outputs in CentAUR are protected by Intellectual Property Rights law, including copyright law. Copyright and IPR is retained by the creators or other copyright holders. Terms and conditions for use of this material are defined in the End User Agreement.

\section{www.reading.ac.uk/centaur}

\section{CentAUR}

Central Archive at the University of Reading

Reading's research outputs online 


\section{Judah Benjamin: marginalized outsider or admitted insider?}

\section{Catharine MacMillan}

Judah Benjamin (1811-1884) was one of the greatest of nineteenth century lawyers. This article analyses how a young man who might have been marginalized in society because of the circumstances of his birth, ethnic origin and religious identity rose to prominence in law, politics and business in the United Kingdom and the United States.

In June, 1883 an extraordinary dinner was held in the Inner Temple. Presided over by the Attorney General, Sir Henry James, two hundred members of the English bench and bar gathered to honour one they recognized as their leading barrister, Judah Benjamin. The event was extraordinary not only in the rarity of such tributes but because the subject of this tribute had arrived as an outsider eighteen years earlier. Benjamin had begun life in the West Indies, the son of an impecunious Jewish merchant with an often precarious and itinerant existence. By his retirement Benjamin had dominated the legal professions of the United States and the United Kingdom, written a major English law treatise, acquired fame (or infamy) as a politician in mid-century America and run a sugar plantation. His obituarist's statement that he had led a "life [that] was as various as an Eastern tale" 1 acknowledged Benjamin's success yet hinted that he was something of an outsider.

\section{A challenging biographical subject}

This article examines aspects of Benjamin's remarkable life to determine how an outsider moved from the margins of society to acquire influence and the nature of the influence acquired. Benjamin was an outsider who became an insider at the top of his chosen professions. Benjamin remains an enigma to historians, an important character who defied attempts to produce critical biographies of himself. "[O]ne of the most secretive men who ever lived", 2 he was buried in Pere Lachaise cemetery in Paris under his wife's family's name. He destroyed his papers to deliberately thwart prospective biographers fearing that his life would be construed according to their prejudices. ${ }^{3}$ While biographies exist, ${ }^{4}$ Benjamin succeeded in preventing a critical assessment of himself and his various roles. This success presents methodological challenges in critically reconstructing his life and assessing its significance.

\footnotetext{
- Professor of Law and Legal History, University of Reading. I would like to thank Georgia Chadwick for her help with the Louisiana cases, JoAnne Sweeny for her help with the United States Supreme Court cases and Margaret Polk for her assistance with the New Orleans commercial court cases. 
A subject who leaves personal papers bequeaths biographers with the material from which a framework of the life can be constructed. In many instances these papers provide insight into the thoughts and emotions of the subject. These papers also provide links to the people and events of the subject's era, links that allow the biographer to set the life in context and assess the context of the subject's life. A subject without personal papers entirely deprives the biographer of significant internal insights into the subject and also hampers the contextualization and critical appraisal of the life in question. It is the case, though, that the subject who leaves personal papers often leaves to the future a particular view of herself and impedes a truly candid and critical perspective. Benjamin's biographers have been hampered by a lack of a corpus of personal papers that has, in turn, led to an unfortunate marginalization of his importance in the legal and political histories of the nineteenth century trans-Atlantic world. Sources of information about Benjamin's life exist, although locating and assessing these sources is a time consuming process.

As a lawyer, Benjamin's life is assessed from a number of surviving sources. He wrote two legal works: Digest of the Reported Decisions of the Superior Court of the Late Territory of Orleans, and of the Supreme Court of the State of Louisiana ${ }^{5}$ and A Treatise on the Law of Sale of Personal Property. ${ }^{6}$ To these publications, one must add the legal arguments he submitted to American and British courts. Detailed searches in private archives may well reveal some of his legal opinions. Law reports, journals, newspaper reports and the occasional transcript provide an indication of his oral arguments. The use of his cases and writings offer an indication into his influence upon the development of the law. To these sources one must also add the observations of his legal contemporaries, often expressed in their memoirs. As a politician, several sources of information exist about Benjamin. One lies in the newspaper reports and the reports of the proceedings of the Senate. A second lies in the Confederate Records held in the Library of Congress, ${ }^{7}$ including a few private papers. A third is in the correspondence of his contemporaries. Finally, while Benjamin did not keep a letter book some of his correspondence survives in the personal papers of others. Some of his Confederate correspondence has been published. ${ }^{8}$ The account that follows draws upon most of these documents. While sources allow a reconstruction of Benjamin's life and his enormous influences, they largely fail to provide insight into Benjamin's thoughts, perceptions and motivations.

This failure is significant not only in the understanding of Benjamin's life but also in a greater understanding of one of the most prominent Jewish figures in the nineteenth century English speaking world. This prevents a greater understanding of the acceptance of Jewish people in America and the United Kingdom. Historians are divided as to the acceptance of Jews in both countries at this time. Neither country suffered the virulent anti-Semitism that resulted in the ghettos and pogroms of central

$5 \mathrm{~J}$ Benjamin and T Slidell (New Orleans, 1834).

6 (London, Henry Sweet, 1868). Benjamin wrote a second edition (London, Henry Sweet, 1873) and supervised a third written by Arthur Beilby Pearson and Hugh Fenwick Boyd (London, Henry Sweet, 1883).

${ }^{7}$ Confederate States of America records, 1854-1889, Library of Congress MSS 16550.

${ }^{8}$ The United States War Department, The War of the Rebellion: a Compilation of the Official Record of the Union and Confederate Armies, series I-IV (Washington, Government Printing Office, 18801901) and United States, Naval War Records Office, Official Records of the Union and Confederate Navies in the War of the Rebellion (Washington, Government Printing Office, 1894-1922). 
and Eastern Europe. These English speaking countries were also largely Protestant with the result that the Catholic minority "were more intensely abhorred than Jews were". ${ }^{9}$ Jews thus suffered the effects of prejudice but this was neither as virulent as occurred elsewhere nor were Jews its greatest victims in either country. In America, Dinnerstein observed, Jews enjoyed full legal equality under the constitution, albeit an equality not fully manifested until after the Second World War. ${ }^{10}$ Benjamin's lived his American life at a time when Jews received a form of political acceptance but suffered considerable disadvantages. His last years in America, during the Civil War, a time of intense stress, were ones in which anti-Semitism 'positively exploded' 11 and Benjamin suffered a series of intense, anti-Semitic attacks that had not occurred earlier in his career. ${ }^{12}$

The historiography of the Anglo-Jewish community changed during the twentieth century. The initial Whig history of a successful advancement to political emancipation ${ }^{13}$ gave way to a much more complex and nuanced view of a community in which British anti-Semitism played a much greater and more destructive role. ${ }^{14}$ Anti-Semitism, it was argued, compelled Jews to conform with the practices of gentiles to gain acceptance. ${ }^{15}$ It must be noted, though, that this later view is not without its critics: for Rubinstein, British anti-Semitism has always existed 'yet it has probably been more subtle, harder to find ... equivocal and contradictory than in any other country'. ${ }^{16}$ An examination of Benjamin's life sheds light on how and why Jews could be accepted within English society and become a leading professional. The argument advanced here is that Benjamin arrived in England at a point in which the role of Jews was in the midst of transition. There was a partial emancipation which allowed Jews increasing civic participation. In 1845 Jews had been declared eligible for important municipal offices and in 1858 Lionel de Rothschild, after long debate, was able to take his seat as the first Jewish MP in Parliament. It was not until 1871, though, that the Universities Tests Act removed the barriers preventing Jews from becoming scholars or fellows in English universities. England still awaited the fiercer anti-Semitism that attended the arrivals of Eastern European Jews fleeing the pogroms of the 1880s. Benjamin's life, it is also argued, demonstrates how some individuals can 'overcome' the initial marginalisation which attends the circumstances of their birth to move within the mainstream of society.

\footnotetext{
${ }^{9}$ Leonard Dinnerstein, Antisemitism in America (Oxford University Press, New York, 1994) X. See also W.D. Rubinstein A History of the Jews in the English-Speaking World: Great Britain (Basingstoke, Macmillan Press Ltd, 1996).

10 Ibid.

11 Dinnerstein, above n 9, 27.

12 Ibid, 33.

13 See, for example, Cecil Roth, History of the Jews of England (Oxford University Press, Oxford 1941) and V.D. Lipman, Social History of the Jews in England 1850-1950 (Watts, London, 1954).

${ }^{14}$ See, for example, Geoffrey Alderman, Modern British Jewry, $2^{\text {nd }}$ ed (Oxford University Press, Oxford, 1998) and David Cesarani, ed, The Making of Modern Anglo-Jewry (Oxford University Press, Oxford, 1990).

15 See, for example, Tony Kushner, The Persistence of Prejudice: anti-Semitism in British society during the Second World War (Manchester University Press, Manchester, 1989).

${ }^{16}$ Rubinstein, above n 9, 34. See, also M.R. Marrus, 'European Jewry and the Politics of Assimilation: Assessment and Reassessment', 49 Journal of Modern History (1977) 89 and A. Gilam, 'A reconsideration of the Politics of Assimilation', 50 Journal of Modern History (1978) 103.
} 


\section{Benjamin the American \\ Childhood}

Benjamin did not begin life as an American. Born in the Caribbean on St Croix in 1811 to Sephardic Jews, Philip Benjamin (probably from St Nevis) and his wife Rebecca (raised in England, possibly born in Holland). ${ }^{17}$ The sketchy knowledge of his parents' origins indicates the migratory nature of their lives. St Croix was then a Danish possession under British occupation, which allowed Benjamin to later assert that he was a British subject. When he was two his family left the West Indies and settled first in Wilmington, North Carolina, then Fayetteville and finally Charleston. Young Judah thus began his existence as an outsider, a Jewish boy who spent his early years moving between communities. The Carolinas formed a part of a wider Caribbean world, dependent upon the waterborne trade of commodities largely produced by slave labours, and Benjamin's West Indian origins were unlikely to have marked him as different. ${ }^{18}$ His later Confederate colleague, South Carolinian George Trenholm, viewed him as "a Carolinian by birth". ${ }^{19}$ His father's naturalisation in 1824 made him an American citizen. Precociously clever and hardworking, the young man was admitted to Yale at fourteen. Benjamin's Southern origins, his Judaism, his youth and his parents' impecuniosity set him apart from his classmates at Yale. While his tutor acknowledged that "he was highly distinguished as a scholar" 20 and popular with his classmates, he abandoned his studies and departed Yale in 1827. Although not expelled, his biographers have considered that his departure was occasioned by misdeeds connected with gambling. ${ }^{21}$

\section{Adulthood}

Penniless, disgraced and only sixteen, a letter to Samuel Stone indicates Benjamin's determination in the face of adversity. Describing himself as both "a gentleman" and "a stranger" Benjamin cogently stated both his practical abilities as a clerk and academic abilities as a scholar seeking employment. ${ }^{22}$ Benjamin returned, however, to his parents in Charleston and wrote to President Day at Yale to beg forgiveness for his "improper conduct" and seeking re-admission. ${ }^{23}$ Before receiving a response Benjamin travelled to New Orleans to make his fortune.

The Yale debacle caused a permanent estrangement from his father ${ }^{24}$ and, it appears, his religious faith. Korn observed that while Benjamin never denied nor abandoned his Judaism he showed no interest in it. ${ }^{25}$ The port city was booming as ever

\footnotetext{
${ }^{17}$ Meade, above, $\mathrm{n} 4,4-6$.

${ }^{18}$ Benjamin demonstrates that the society of the Southern states, prior to the Civil War, were a part of a more cosmopolitan Caribbean world dependent upon and constructed around slavery: M Guterl, American Mediterranean: Southern Slaveholders in the Age of Emancipation (Cambridge, Mass, Harvard University Press, 2008) ch. 2.

${ }^{19}$ Letter from George Trenholm to Charles Prioleau, 5 July 1866, Business Records of Fraser, Trenholm \& Company, Merseyside Maritime Museum, Liverpool B/FT Box 1/134.

${ }^{20}$ Letter from Simeon North to Mr Brayton, 30 January 1827 [probably 1828], Library of Congress MMC, mm79000172.

${ }^{21}$ See, for example, Meade, above, n 4, 22-30; Butler, above, n 4, 26-31. The allegation shocked those who knew the young Benjamin: B Korn, The Early Jews of New Orleans, (Waltham, Massachusetts, American Jewish Historical Society, 1969), 187, quoting Jacob Florance.

${ }^{22}$ Letter from Benjamin to Simon Stone, 15 November 1827, Library of Congress, above, $\mathrm{n} 7$.

${ }^{23}$ Letter from Benjamin to Jeremiah Day, quoted in Meade, above, n 4, 29-31.

${ }^{24}$ Evans, above, n 4, 22.

25 B Korn, 'Judah P Benjamin as a Jew', (1949) American Jewish Historical Society, 153, 171.
} 
increasing amounts of commodities moved down the Mississippi and into the Atlantic. $^{26}$ One of the great commercial metropolises of the mid nineteenth-century world, New Orleans grew faster than any other city in America between 1830 and 1840. Such a city needed clever and enterprising young men to exploit its opportunities. It was also a city in which "anti-Jewish prejudice was notable for its absence" 27 and "every indication points to a broad-scale acceptance of Jews by both the Creole and Yankee societies of New Orleans". ${ }^{28}$ Salomon de Rothschild, visiting New Orleans in 1861 wrote "what is really quite astonishing here . . . is the high position occupied by our co-religionists". ${ }^{29}$ In the antebellum South "there was a direct causal relationship between the hospitable treatment accorded Jews and the abominable treatment meted out to blacks". "A white minority feared for its own position and accorded a more favourable treatment to Jews. Anti-Semitism became more prominent after the Civil War as Jewish immigration increased. ${ }^{31}$

Benjamin likely worked for the notary Greenbury Stringer and banker Samuel Hermann. ${ }^{32}$ In multilingual Louisiana, Benjamin learned French and Spanish. He studied law independently and was called to the Louisiana Bar in December, 1832. Shortly after, aged twenty-one, he married Nathalie St. Martin, then sixteen. The marriage was highly significant for Benjamin's future endeavours in law and politics. New Orleans in the 1830 s was a city in transition. Its early settlors were French and Spanish and while the Louisiana purchase of 1803 placed it firmly within an American world, French Creoles ${ }^{33}$ still maintained a powerful presence. The St. Martins were French Catholics who had fled to the United States following the SaintDomingue slave uprisings. Nathalie's family was wealthy and prominent within the powerful French speaking community. Importantly for a young attorney, her father, Auguste St Martin, was the secretary of the Orleans Insurance Company and then president of the Orleans Navigation Insurance Company. Insurance generates legal work and Benjamin appears to have represented Auguste. ${ }^{34}$ That the family were French Catholics helped Benjamin if not to assimilate within Creole society, at least to align himself with it. His law offices were always on the western edge of the Vieux

\footnotetext{
${ }^{26}$ S. Marler, The Merchants' Capital: New Orleans and the Political Economy of the NineteenthCentury South (Cambridge University Press, New York, 2013) ch 1.

${ }^{27}$ Korn, above, $\mathrm{n} 21,223$.

${ }^{28} \mathrm{id}, 225$.

${ }^{29}$ (ed.) S Diamond, A Casual View of America: The Home Letters of Salomon de Rothschild, 18591861 (Stanford University Press, Stanford, 1961)115.

${ }^{30}$ J Sarna, "Review The Jewish Confederates" in (2001) 89 Am Jewish History 335, 336.

${ }^{31}$ A Rockaway and A Gutfeld, "Demonic Images of the Jew in the Nineteenth Century United States", (2001) 89 Am Jewish History 355, 373. Other factors existed: E Goldstein, "Different Blood Flows in Our Veins: Race and Jewish Self-Definition in Late Nineteenth Century America", (1997) 85 Am Jewish History 29.

${ }^{32}$ Both witnessed Benjamin's marriage contract: Notarial Archives Research Center, New Orleans, Records of Louis Feraud, vol 7, 58-58A,12 February 1833.

${ }_{33}$ As a term 'creole' has assumed many meanings. It is used here in the sense applicable to the St Martins, persons of French descent born outside France.

${ }^{34}$ See, for example, St Martin v Peychaud, First District Court, 19 February 1834, docket no. 11057, Louisiana Division City Archives \& Special Collections, New Orleans Public Library; Garnier v Succession of Peychaud (1836) 9 La 182, court records available at the Earl K. Long Library, The University of New Orleans <http://hdl.handle.net/123456789/11555>.
} 
Carré, ${ }^{35}$ just within the French quarter but close to the increasingly important Americans. Judging by his court appearances, Benjamin had a significant client base within the French community. It has been said that the St. Martins allowed this marriage because Nathalie had scandalised society ${ }^{36}$ but there are no discernible foundations for such a theory. For the St. Martin family, the 1830s were a vital point in New Orleans development as the political, legal and commercial control of the city slipped from the French to the incoming Americans. A daughter's marriage to an American would have been advantageous for a prominent Creole businessman. ${ }^{37}$ Benjamin himself was ever engaging and portraits reveal a handsome young man. Whatever the reason for the marriage, the relationship Benjamin had with his in-laws was a close one.

The Benjamin marriage was also unusual because they lived apart for most of their married life. Nathalie has been depicted as a shallow woman or a promiscuous profligate, and thus the spouse who caused this separation. ${ }^{38}$ This depiction does a disservice to her. Creole women were rarely educated and, unsurprisingly, she has not left papers. The reasons behind her departure to Paris with their young daughter Ninette around 1845 have never been clearly explained. The Benjamins were married a decade before the birth of their only child, to whom they were devoted. The decision to raise her in France was a rational one. The French in the Caribbean did have a practice of educating children in France and nineteenth century New Orleans was not a healthy city, as contemporaries realised. ${ }^{39}$ The humid, foetid, crowded port city was plagued by disease. Inhabitants particularly feared yellow fever, "repulsive and treacherous ... its fatal ending is inexpressibly terrible". ${ }^{40}$ While this highly contagious disease was brought to the Americas with enslaved Africans and was transmitted by Aedes aegypti mosquitoes, in the nineteenth century it was thought that it was borne on or originating in the foul atmosphere of the bayous. Yellow fever, it was noticed, particularly attacked newcomers, notably Americans and Europeans. ${ }^{41}$ Benjamin's mother died of it in 1847. There is also a suggestion that Ninette suffered from a "lifelong disorder" 42 and may well have needed greater medical care.

Benjamin visited his family in Paris regularly. ${ }^{43}$ He developed professional connections in Paris on these visits, something which gave him different perspectives and connections than Southern contemporaries. Benjamin remained close to

\footnotetext{
${ }^{35}$ Michel's New-Orleans Annual and Commercial Register for 1834 (New Orleans, Gaux and Sollee, 1833) 20,195; Gibson's Guide and Directory of the State of Louisiana and the Cities of New Orleans and Lafayette (New Orleans, John Gibson, 1838) 15, 195; Michel \& Co New Orleans Annual and Official Commercial Register for 1846 (New Orleans, Michel, 1846) 81, 534.

${ }^{36}$ W De Ville, “The Marriage Contract of Judah P. Benjamin and Natalie St. Martin, 1833”, (1996) 37 The Journal of the Louisiana Historical Association 81, 84.

${ }^{37}$ See, generally, J Tregle, Jr, "Creoles and Americans" in A Hirsch and J Logsdon (eds) Creole New Orleans: Race and Americanization (Baton Rouge, Louisiana State University, 1992).

${ }^{38}$ Butler, above, n 4, 34-36; Meade, above, n 4, 34-36; and Evans, above, n 4, 33-35.

${ }^{39}$ Commercial Directory (Philadelphia, Kayser \& Co, 1823) 226.

${ }^{40} \mathrm{G}$ Cable, The Creoles of Louisiana (1884, reprinted Gretna, LA, Pelican Pouch, 2005$) 301$.

41 J Carrigan, "Privilege, Prejudice, and the Strangers' Disease in Nineteenth-Century New Orleans", (1970) 36 The Journal of Southern History 568.

${ }^{42}$ Letter from Benjamin to Rebecca Levy, 29 September 1865, quoted in Butler, above, n 4, 370-372, stating that he found Ninette "in perfect health ... now radically cured . . . and looking as blooming as a rose": 371

${ }^{43}$ The Times, 9 May 1884, 10.
} 
Nathalie's father and particularly close to her brother, Jules who accompanied him to a variety of places, despite his difficulties in speaking English. ${ }^{44}$ In short, Benjamin's unusual marriage was one which gave him advantage as an attorney and served to broaden his connections and horizons later in life.

\section{New Orleans attorney}

It is striking how quickly and successfully Judah Benjamin's law practice developed. The nature of this practice has never been analysed and space limits this article to a few observations concerned with Louisiana law and Benjamin's cases. Louisiana then, as now, was a civil law jurisdiction. Benjamin's legal colleague, Christian Roselius, observed that "it is evident that the principal foundations of the laws of this State, in civil matters is, the Roman law . . . hence . . . the study of the Roman Law, in connection with our own Code, is indispensably necessary for a thorough understanding of the laws of Louisiana". ${ }^{45}$ The first Louisiana Digest of 1808 was a mixture of French and Spanish law and, in turn, provided that after the promulgation of the Code the Spanish, Roman and French laws in force in the state when Louisiana was ceded to the United States would remain in force for every instance not provided for in the Code. ${ }^{46}$ After the Code of 1825 , Louisiana courts still consulted the writings of Spanish and French jurists.

Billings suggests that the Louisiana Supreme Court played a conscious role in the development of Louisiana's civil heritage by establishing the requirements necessary to practise law. By 1840 prospective lawyers were required to undertake a course of legal studies composed of international law, Louisiana law, civil law (primarily Justinian, Domat and Pothier) and the common law. ${ }^{47}$ Benjamin as a practitioner and an author assumed a role in the development of nineteenth-century Louisiana law. In doing so, he drew upon a rich civilian heritage to apply the law to New Orleans' complex commercial and proprietary issues. ${ }^{48}$ Benjamin's 1834 Digest of the Reported Decisions summarises Louisianan law and its mixed heritage. Benjamin wrote The Digest to teach himself Louisiana law, for his "personal convenience", 49 but, with the assistance of Thomas Slidell, published the work as a lawyers' reference.

\footnotetext{
${ }^{44}$ W. Russell, My Diary North and South (ed.) E. Berwanger (Baton Rouge, Lousiana State University, 1988) 130 recounts that Jules spoke English with difficulty.

${ }^{45}$ C Roselius, "Introductory Lecture (1854)", in M Hoeflich, The Gladsome Light of Jurisprudence (Greenwood Press, Westport, Connecticut 1988) 236.

${ }^{46}$ Art. 3521. Louisiana is best described as a mixed law jurisdiction. On the political and legal compromises presented in the formation of this jurisdiction, see V Palmer, "To Worlds in One: The Genesis of Louisiana's Mixed Legal System, 1803-1812" in V Palmer (ed) Louisiana: Microcosm of a Mixed Jurisdiction (Durham, North Carolina, Carolina Academic Press, 1999) and G Dargo, Jefferson's Louisiana: Politics and the Clash of Legal Traditions, rev ed (Clark, New Jersey, The Law Book Exchange, 2009) ch. 6-7.

${ }^{47}$ W Billings, "A Course of Legal Studies", in (eds) W Billings and M Fernandez, A Law Unto Itself?: Essays in the new Louisiana Legal History (Baton Rouge, Louisiana State University Press, 2000) 25.

${ }^{48}$ Early nineteenth century Louisiana was characterized by attempts, beginning with the Digest of 1808 , to limit the courts to law found within legislative enactments and to suppress the use of Roman, Spanish and French law. The Louisiana Supreme Court, however, in Cottin v Cottin (1817) and Fowler v Griffith (1827) held that it could refer to the older sources of law and, after 1828, referred to its own cases as a means of applying the older sources of law. Benjamin and Slidell's Digest was thus a means by which this process could be facilitated.

${ }^{49}$ Above, n 5, 1.
} 
This was a purpose ably fulfilled. ${ }^{50}$ Although Benjamin sought "to present a full statement of every point or principle decided in every case" more in the nature of brief rules arranged alphabetically than principles supported by reason or precedent and arranged within a coherent thesis. Although the scheme has a common law structure it was concerned with how to apply legal rules from largely civilian legal systems within Louisiana.

Without records, it is difficult to ascertain with certainty the nature of the young attorney's practice. Some insight is provided by the law reports and certain surviving legal documents. The exploitation of the natural resources of the land that drained into the Mississippi and the shipping of the resulting commodities required a sophisticated legal framework. Benjamin was an active and successful attorney in this commercial framework. The law reports record his presence in cases involving real property (including slaves), personal property, mortgages, probate and inheritance, negotiable notes, insolvency, insurance, shipping and so forth. These cases also demonstrate Benjamin's knowledge of the Louisiana Code and the Spanish $^{52}$ and French ${ }^{53}$ law underlying Louisiana law. Benjamin was also to employ the works of common law authors in his arguments. ${ }^{54}$ The mixed nature of Louisiana law meant that cases could be considered and decided by reference to the common law with a civilian analysis long before such a practice occurred in England. ${ }^{55}$ Benjamin seems to have excelled not only in his legal analsysis but also in his legal oratory and ability to deal with witnesses. $^{56}$

Benjamin's clients were largely commercial parties, corporations, such as the New Orleans Insurance Company, ${ }^{57}$ and wealthy individuals, notably powerful Frenchmen. A question often relevant to the role of marginalised persons within law is their involvement with other marginalised persons. In Benjamin's case, the answer is ambiguous. One of his earliest cases was Boisdere v Citizens' Bank of Louisiana ${ }^{58}$ in which he represented free persons of colour and successfully established denied attempts to prevent them from ownership of the Bank's stocks. He also represented Genevieve Robert, a free woman of colour, in her attempt to claim a part of the estate

\footnotetext{
${ }^{50}$ F Jumonville, “"Formerly the Property of a Lawyer" -Books that Shaped Louisiana Law", (2009) 24 Tulane European and Civil Law Forum 161 and Anon, "Jurisprudence of Louisiana", (1846) vol 1 The Commercial Review of the South and West, 414, 415

${ }^{51}$ id., 1.

${ }^{52}$ See Gasquet v Dimitry (1836) 9 La. 592; Lyon v Fisk (1846) 1 La. Ann. 444; and Succession of McGill (1851) 6 La. Ann. 327.

${ }^{53}$ See Municipality No. 2 v Hennen (1840) 14 La. 559; McCargo v New Orleans Ins. Co (1845) 10 Rob. (LA) 202; Harman v Claiborne (1846) 1 La. Ann. 342; Shepherd v The Orleans Cotton Press Company (1847) 2 La. Ann. 100

${ }^{54}$ See Tio v Vance (1837) 11 La. 199 (citing Abbott on Shipping; Kent's Commentaries and Phillips on Insurance) and Lanfear v Blossman (1846) 1 La. Ann. 148 (citing Chitty on Contracts).

${ }^{55}$ See , the judgment of Garland J in Wiggin v Flower (1843) 5 Rob. (LA) 406 in which he explained Chitty on Contracts in light of Pothier's Traité du Contrat de Change (Benjamin appeared as counsel).

${ }^{56}$ A Hall, "Cross-Examination as an Art", (1893) 5 Green Bag 423, 423. A contemporary parallel to Benjamin can be found in F.A. Mann: upon whom see G Lewis, F.A. Mann A Memoir (Oxford and Portland, Oregon, Hart Publishing 2013).

${ }^{57}$ McCargo v New Orleans Ins. Co (1845) 10 Rob. (LA) 202 is the principal case in which Benjamin represented the insurers in claims over the value of slaves emancipated by the British after the slaves revolted and took the ship to Nassau. Benjamin's clients were found not liable to pay partly on the basis that slavery was against the law of nature but was allowed by the law of nations.

58 (1836) 9 La. 506.
} 
of her deceased daughter. ${ }^{59}$ These were, though, cases which involved large sums of money, where the individuals could afford good legal representation, and Benjamin's motivation was probably not altruism.

\section{Sugar Master}

Benjamin was quickly recognised by contemporaries as "emphatically the Commercial Lawyer of our city, and one of the most successful advocates at our bar . .. and holds a deservedly high place among the members of his profession". ${ }^{60}$ This enormous success allowed him to enter the commercial activities of Louisiana. His most significant venture was the purchase, with Theodore Packwood, in December $1844^{61}$ of the Bellechasse sugar plantation, six miles from New Orleans. The purchase included a hundred and eight named slaves. As a plantation owner, Benjamin had reached the apex of Louisiana society. He was a sugar master, one of a class of which managed to develop Louisianan sugar through a unique combination of an existing southern slaveholding with modern industrialist practices and plantation capitalism. ${ }^{62}$ Benjamin took an active interest in the process, describing the sugar planter as "manufacturer as well as agriculturist". ${ }^{63}$ Writing in De Bow's Commercial Review he described how to most profitably grow, mill and refine sugar using the new Rillieux vacuum system. He wrote to show how "the industry and enterprise of our population shall succeed in developing to their full extent the resources which a bounteous Providence has lavished on this favoured land". ${ }^{64}$ This development came at enormous cost given its dependency upon slavery. Sugar is a labour intensive crop to produce and the condition of the slaves forced to labour on the sugar plantations was a desperate one. In his unique account of Louisiana enslavement, Solomon Northup wrote that "the oppressors of my people are a pitiless and unrelenting race". ${ }^{65}$ So severe was this treatment that the enslaved African population of Louisiana decreased. ${ }^{66}$

\section{Politician}

It is difficult to categorise the plantation owner as an outsider. A contemporary described Benjamin as "by birth, and as his name imports, an Israelite" although with questionable adherence to "the religion of his fathers"; ${ }^{67}$ such a description does not marginalise him. Benjamin was elected a Whig member of the legislature in 1842 . Louisiana had particularly restrictive suffrage and officeholding requirements which meant that election was dependent upon the backing of the powerful ${ }^{68}$ and in New Orleans, this came from the French community. This indicates a high degree of social

\footnotetext{
${ }^{59}$ Robert v Allier's Agent (1841) 17 La. 4 and Succession of Robert (1842) 2 Rob. (LA) 427.

${ }^{60} \mathrm{~J}$ Whitaker, Sketches of Life and Character in Louisiana (Ferguson \& Crosby, New Orleans, 1847) 27.

${ }^{61}$ New Orleans Notarial Archives, vol 12A D.L. McCay, act 263, 10 December 1844.

${ }^{62}$ R Follett, The Sugar Masters Planters and Slaves in Louisiana's Cane World, 1820-1860 (Baton Rouge, Louisiana State University Press, 2006) describes in detail the processes by which this was undertaken.

${ }^{63}$ J Benjamin, "Louisiana Sugar” in (1847) vol II The Commercial Review 322, 331. ${ }^{64}$ id., 345.

${ }^{65}$ S Northup, Twelve Years a Slave (1853, reprinted London, Penguin Classics, 2014) 175. The memoir was adapted by screenwriter John Ridley "12 Years a Slave" which details the experiences of Louisiana slaves.

${ }^{66}$ Follett, above, n 62, 77.

${ }^{67}$ Whitaker, above, n 60, 28. Later analysis confirms this: B Korn, “Judah P. Benjamin as a Jew”, (1948) 38 American Jewish Historical Society 153, 168.

${ }^{68}$ J Sacher, A Perfect War of Politics (Baton Rouge, Louisiana State University Press, 2003) 12.
} 
inclusion and very real political power. In 1853 the state legislature elected him to the United States Senate; Benjamin had already declined President Fillmore's nomination to the United States Supreme Court. It is said that Benjamin later remarked that had he been less ambitious he would have ended his days on the Supreme Court bench. ${ }^{69}$

The 1850s Senate was a challenging environment as the republic struggled with slavery. Russell, of The Times, wrote that Benjamin was "the most brilliant perhaps of the whole of the famous Southern orators" "70. Benjamin spoke to support states' rights, notably the right to own slaves. While he had sold Bellechasse on entering the Senate he remained acutely conscious of the economic ramifications of slavery and the dependence of southern wealth upon it. As Benjamin observed the ownership of slaves was worth over four thousand million dollars and was a right guaranteed by the constitution. ${ }^{71}$ Perceptive, calm and reasoned, Benjamin's arguments were powerful because they took a variety of forms. He argued not only the economic and political expediencies of slavery but also its legal position. ${ }^{72}$ Some have stated that the brilliancy of his arguments led his opponents to personal attacks. Evans wrote that during debates about the extension of slavery into Kansas, Senator Wade from Ohio referred to Benjamin as an "Isrealite with Egyptian principles" before $^{74}$ and after ${ }^{75}$ Evans. The context of Wade's speech makes it clear that he was addressing not Benjamin but the doughfaces, Northern Democrats allied with Southern Democrats. ${ }^{76}$ The comments Wade addressed personally to Benjamin, who was not present in the chamber for most of the speech, ${ }^{77}$ complimented him, referring to "that plausible and beautiful style of which he is so completely master" ${ }^{78}$ noting that he was "the able and eloquent gentleman from Louisiana" gifted mind". ${ }^{80}$

This is not to say that Benjamin did not suffer racist treatment during his political career. The many references to his "Hebrew" or "Isrealite" origins indicate others viewed him as an outsider. The racism he encountered in the Senate likely took a far more insidious form than slurs hurled in debates, something apparent in an interaction with Jefferson Davis. In a debate about the purchase of firearms, Benjamin and Davis disagreed and the latter accused the former of misrepresentation. ${ }^{81}$ Davis suspected Benjamin of advancing the mercantile interests of a client by seeking greater funds

\footnotetext{
${ }^{69}$ Neiman, above, n 4, 74.

${ }^{70}$ W Russell, My Civil War Diary, (ed.) F Pratt (Hamish Hamilton, London, 1954) 96.

${ }^{71} \mathrm{~J}$ Benjamin, Speech of Hon. J. P. Benjamin of Louisiana, on the Right of Secession, (Senate of the United States, Dec. 31, 1860) 15.

${ }^{72}$ See, for example, the speech delivered on March 11, 1858 "Slavery Protected by the Common Law of the World" in which he argued that the institution had come from England and had thus been protected under the United States constitution.

${ }^{73}$ Evans, above, n 4, 95-96.

${ }^{74}$ B Hendrick, Statesmen of the Lost Cause (The Literary Guild of America, Inc, New York, 1939) 173

75 . Rosen, The Jewish Confederates (Columbia, University of South Carolina Press, 2000) 64.

${ }^{76}$ Congressional Globe, $35^{\text {th }}$ Congress, $1^{\text {st }}$ session, 1115 . Wade began stating that "the doughfaces of the North . . . are the most despicable of men. The modern doughface is not a character peculiar to the age in which we live, but you find traces of him at every period of the world's history": id.

${ }^{77}$ id, 1114.

78 id, $1114-1115$.

$79 \underline{\mathrm{id}}, 1115$.

80 id.

${ }^{81} \overline{\mathrm{id}}_{\mathrm{i}}, 2781-2782$.
} 
and accused Benjamin of being a "paid attorney". 82 Benjamin's reported responses were courteous but, off the record, he challenged Davis to a duel. Benjamin's actions constituted a defence according to the honour code of the day: an insider's actions. Davis privately admitted his error to Benjamin. Although earlier accounts of this event have Davis issuing a public apology in the Senate, the apologist was actually Senator Pearce who made a "statement of fact" that his innocent mistake had caused the disagreement. ${ }^{83}$ In short, it seems likely that Benjamin's Senate experiences were not ones of insults hurled on the floor but in dealing with the far less perceptible prejudices of those he referred to as his "brother Senators". A similar form of insidious anti-Jewish sentiment is clearly seen in the diary of the Confederate clerk, J.B. Jones. ${ }^{84}$

A significant aspect of Benjamin's Washington life was his practice before the United States Supreme Court. He was admitted to practice in 1848, in the same term as Abraham Lincoln. Benjamin appeared frequently and successfully before the Court. Benjamin represented clients from the south, notably Louisiana. The disputes were commercial cases of the sort he had taken in New Orleans: bankruptcy; ${ }^{85}$ shipping; ${ }^{86}$ estate and succession; ${ }^{87}$ and land disputes. ${ }^{88}$ One of his most prominent cases was the United States v Andres Castillero, ${ }^{89}$ a case concerned with the ownership of the New Almaden quicksilver mine in California. Benjamin and Reverdy Johnson appeared more frequently before the Taney Court than any other lawyers. ${ }^{90}$

When Louisiana seceded from the United States in January 1861 her senators left their seats. A recent re-appraisal of Benjamin argues that he accepted the inevitability of southern secession and willingly left the union. ${ }^{91}$ This marked the end of one political career for Benjamin and the beginning of another. It is with regard to Benjamin as Confederate that the lack of personal papers providing insight into his thoughts and actions is most critically felt. It is highly doubtful that Benjamin would have wanted the Confederate States to engage in a lengthy war with the United States as Benjamin was clever enough to realise that a prolonged engagement was one the Confederacy could not win. Benjamin, the logical lawyer, likely thought that constitutional law favoured the Confederacy and that the great commodity purchasers of cotton, the United Kingdom and France, would recognise the new nation. Lacking personal papers, though, only a glimpse of this reasoning can be seen from his comments to others. ${ }^{92}$

\footnotetext{
${ }^{82}$ Evans, above, $\mathrm{n} 4,99$ relying upon the notes of Thomas Bayard.

${ }^{83}$ Congressional Globe, above, $\mathrm{n} 76,2823$. Davis replied to this statement but the reply takes the form of an explanation not an apology: id., 2824.

${ }^{84}$ J Jones, A Rebel War Clerk's Diary, vol I (J.B. Lippincott \& Co, Philadelphia, 1866) 118.

${ }^{85}$ Ingraham v. Dawson (1857)61 U.S. 486; Jeter v. Hewitt (1859) 63 U.S. 352; and Adams v. Preston (1859) 63 U.S. 473

${ }^{86}$ Culbertson v. The Steamer Southern Belle (1855) 59 U.S. 584; Goslee v. Shute (1855) 59 U.S. 463; and Ure v. Coffman (1856) 60 U.S. 56.

${ }^{87}$ McGill v. Armour, (1850) 52 U.S. 142 and Poydas v. Treasurer of Louisiana (1855) 59 US 192.

${ }^{88}$ Foley v. Harrison (1853) 56 U.S. 433; Cousin v. Labatut (1856) 60 U.S. 202; and Spencer v. Lapsley (1859) 61 U.S. 264.

${ }^{89} 67$ U.S. 17.

${ }^{90}$ H Connor, John Archibald Campbell (Houghton Mifflin Company, Boston, 1920) 83.

${ }^{91}$ G Cunningham, "'The Ultimate Step": Judah P. Benjamin and Secession", (2013) 97 Am Jewish History 1.

${ }^{92}$ Benjamin told Russell that England was bound to recognize the Confederacy: Russell, above, n 37 , 128.
} 
Benjamin was central to the Confederate government. He was, in succession, the Attorney General, the Minister of War and the Secretary of State. The pictorial depictions of the cabinet invariably display him beside or behind Jefferson Davis, the implication being that Benjamin guided the President. Benjamin's loyalty to Davis was great. The Confederacy was poorly equipped for war and this led to the loss of many lives at Roanoke Island. Rather than publicly expose this weakness, and Davis to censure, Benjamin assumed responsibility and suffered condemnation as the "fat Jew sitting at his desk". ${ }^{93}$ The Civil War brought a spate of anti-Semitic attacks on Jewish figures. The most public of these was General Grant's order to expel all Jews from his department ${ }^{94}$ but Jews were publicly blamed for many disasters that befell both sides. The diarist Mary Chesnut recorded that the mob referred to Benjamin as "Mr. Davis's pet Jew". ${ }^{95}$ Benjamin's reception at a personal level was a different matter, though, for Chesnut also observed after meeting him that "he is a Delphic oracle", ${ }^{96}$ a man her husband thought the Senate's cleverest southerner. ${ }^{97}$ Despite the anti-Semitic attacks on his character and the suspicions harboured by many Confederates, Benjamin worked ceaselessly for what he must have recognised early on was a "lost cause".

The end of the war found Benjamin in a particularly difficult situation. ${ }^{98}$ Implicated in Lincoln's assassination, distrusted by many southerners in an anti-Semitic environment and with a reward for his capture, he stated that he would never be taken alive. Had he been caught, he stated later that year, "they probably would have put him to death". ${ }^{99}$ His fears were real. The New York Times, named Davis, Benjamin and Breckenridge and thundered that "the leading traitors should die the most disgraceful death known to our civilization -death on the gallows". ${ }^{100}$ The insider had become an outsider again.

\section{Benjamin the Briton}

Benjamin fled to Britain as a safe haven and it is possible that he did not consider himself a British subject. ${ }^{101}$ He settled early on the idea of a legal career in England. He wrote to his sisters that he was "almost fixed in my purpose to practice my profession as barrister in London, but have not yet decided" as he ascertained the requirements for the admission of strangers. ${ }^{102}$ His intention was reported in more definite terms in The Solicitors' Journal: "it is said that Mr. Benjamin, ex-Secretary of State in the Confederate Government, intends joining the English Bar". ${ }^{103}$

\footnotetext{
${ }^{93}$ Evans, above, n 4, 147.

${ }^{94}$ See J Sarna, When General Grant Expelled the Jews (Schocken Books, New York, 2012).

${ }^{95}$ Mary Chesnut's Civil War, (ed.) C Vann Woodward (Yale University Press, New Haven and London, 1981) 288.

${ }^{96} \mathrm{id}, 542$.

${ }^{97} \overline{\mathrm{id}}, 288$.

${ }^{98}$ Gruss, above, n 4, 964-970.

${ }^{99}$ C Pollock, "Reminiscences of Judah Philip Benjamin”, (1898) 10 Green Bag 396, 397.

${ }^{100}$ The New York Times, 1 May $1865<$ http://www.nytimes.com/1865/05/01/news/the-importance-ofcapturing-the-rebel-chiefs.html> .

${ }^{101}$ In a letter to his sister, Benjamin wrote that he would probably have to be naturalized to become a barrister: Benjamin to Rebecca Levy, 29 September 1865, quoted in Butler, above, n 4, 370-372. 102 id, 371.

${ }^{103}$ Vol 9 Solicitors' Journal and Reporter, 23 September 1865,1002.
} 
To outward appearances, Benjamin was a complete outsider when he arrived in Southampton in August 1865: "it is difficult to imagine a position more apparently hopeless than his". ${ }^{104}$ At the relatively advanced age of fifty-five, Jewish, not only American but also a Confederate and seemingly friendless in an alien land, the odds were against success. Even the intention to practise law seemed optimistic as he presented himself in a common law country having trained and practised in America's civil law jurisdiction. Appearances were deceptive and Benjamin made the most of any advantage offered. He began by utilising the network he had established as Confederate Secretary of State. He went upon arrival to 17 Savile Row, ${ }^{105}$ the residence of Henry Hotze, one-time chief Confederate propagandist formerly supervised by Benjamin. It was true that Benjamin was often proscribed for his previous advocation of slavery (curiously, few Britons seem to have realised that he had also been a major slave owner and this he kept to himself) but the Civil War had divided British allegiances. Benjamin was quick to accept sympathetic hands extended to him. A month after his arrival Benjamin wrote that various members of parliament had called upon him, Benjamin Disreali offered assistance and he would dine with William Gladstone.

Social contacts within political levels are not enough, though, on their own to overcome the various barriers Benjamin encountered on his arrival in London. While the legal profession in antebellum America was one into which a great diversity of men had entered, the same was not true of the English Bar. Here the advocates of the legal profession were overwhelmingly English, Anglican, and the sons of professional men or the landed aristocracy. ${ }^{106}$ Successful barristers had generally attended a public school. ${ }^{107}$ There was a 'near absence of the lower orders of society' and the sons of small shopkeepers were not represented amongst the Bar. ${ }^{108}$ Jewish barristers were almost non-existent. On the face of it, the reception of a Jewish American lawyer, the son of a many failed shopkeeper, was unlikely.

That Benjamin was a stranger was apparent to observers. He was described as a "prince of the Secession", 109 "of decidedly Jewish descent", 110 "a little elderly man, snuffy and ill-shaven, with nothing to captivate men"111 and one who spoke "with a strong American accent". ${ }^{112}$ Analysing his establishment at the bar it is clear, though, that this was made possible because he was Jewish and because he was a Confederate. Those factors which made him an outsider he utilised to move inwards. Describing himself as "a Political Exile, proscribed for my loyalty to my own State", 113

\footnotetext{
${ }^{104}$ Anon, “Judah P. Benjamin” (1889) 1 Green Bag 365, 365.

${ }^{105} \mathrm{~J}$ Witt, Life in the Law (T. Werner Laurie, London, 1900) 160.

${ }^{106}$ D Duman, The English and Colonial bars in the nineteenth century (Croom Helm, Beckenham, 1983),9-15.

107 id, $107-109$.

108 P Polden, "The Legal Professions", The Oxford History of the Laws of England, vol XI (Oxford University Press, Oxford, 2010), 1021.

${ }^{109}$ The Law Times, 17 February 1883, 278

${ }^{110}$ Pollock, above, n 99, 397.

${ }^{111}$ R Palmer, Earl of Selborne, Memorials Part II. Personal and Political 1865-1895 (Macmillan, London, 1898) 94.

${ }^{112}$ Anon, A Generation of Judges by their Reporter (Sampson, Low, Marston, Seale and Rivington, London, 1886) 198.

${ }^{113}$ The Records of the Honourable Society of Lincoln's Inn (Lincoln's Inn, London 1991-2001) vol 5, 133.
} 
Benjamin applied for admission to Lincoln's Inn in January 1866. He sought and received an exemption from preliminary examination. The Benchers then dispensed with their requirements as to terms and admitted Benjamin after a single term. While Sir Henry James stated at Benjamin's farewell banquet that "from the first days of his coming he was one of us"114 it is clear that there was resistance to his call to the bar. A contemporary account of his 'unreasonable' call to the bar wondered "what peculiar claim Mr. Benjamin can have upon the Benchers of Lincoln's Inn" "115 in having almost all of his terms remitted. ${ }^{116}$ Suspicions lingered that Benjamin's early call was attributed to Confederate sympathies at the bar. ${ }^{117}$

At his farewell banquet, Benjamin thanked a number of Benchers for their assistance when he arrived. One was Baron Hatherley, then Page Wood V-C. As an MP, Page Wood, a High Churchman and a Liberal, had led the debates about the removal of Jewish disabilities and was at the forefront in the admission of Lionel de Rothschild to the House of Commons. In Benjamin, Page Wood saw the opportunity of presenting the bar with a gifted Jewish lawyer. His presence at Benjamin's call ceremony on 6 June 1866 was noted. ${ }^{118}$ The first Jewish barrister, Francis Goldsmid, had been called in 1833. To practise before the bar, students were required to swear an oath "upon the true faith of a Christian". The oath was anti-Catholic in origin and derived from legislation designed to bar from public offices those who would not take the Church of England sacrament. In Goldsmid's case the benchers of Lincoln's Inn, eventually agreed to allow him to dispense with the Christian phrase. Goldsmid, however, was not followed by many other Jewish lawyers ${ }^{119}$ and this assists in the understanding of Page Wood's intervention.

As has been observed, Benjamin's England as one that accepted Jews in many ways. While prejudice, often most viciously displayed, ${ }^{120}$ was still evident it was also the case that following their emancipation in the late 1850 s, Jews were able to participate in political life. A significant portion of the Anglo-Jewish community was "irreverent, if not irreligious" 121 and Jews were emancipated Englishmen. ${ }^{122}$ Benjamin, experienced in living within a gentile society, accustomed himself to this new environment. This gives credence to the view that his acceptance was conditioned upon his assimilation but without an insight into Benjamin's own thoughts it is impossible to prove that his assimilation occurred to gain acceptance.

Benjamin was able to find a place in the chambers of Charles Pollock, then a leading commercial barrister, through the intercession of his father, Chief Baron Pollock. It appears that Benjamin had James Mason take him as a guest to Lord Chief Baron

\footnotetext{
${ }^{114}$ Remarks of the Attorney General and the Response of Mr Judah P Benjamin at the Dinner in the Inner Temple Hall, London, June 30, 1883 (privately printed, undated) 6 .

${ }^{115}$ The Jurist, 9 June1866, 238.

${ }^{116}$ The Benchers at Lincoln's Inn also considered an inquiry from Gray's Inn asking if they had called

Mr Benjamin to the Bar without him having kept the required terms: above, $\mathrm{n} \mathrm{113,} 140$.

${ }^{117}$ Reynold's Newspaper, 3 June 1866, 2.

${ }^{118}$ Daily News, 8 June 1866, 8; The Jurist, above, n 109.

119 See Phyllis S Lachs, 'A Study of a Professional Elite: Anglo-Jewish Barristers in the Nineteenth Century', (1982) 44 Jewish Social Studies 125 for a thorough examination of the subject.

${ }^{120}$ See, for example, the treatment which could be accorded Jewish political candidates: M. Clark, Albion and Jerusalem (Oxford University Press, Oxford, 2009) 62-64.

${ }^{121} \mathrm{id}, 193$

122 id, 248.
} 
Pollock's country house. Mason was the man Benjamin had sent to London as the Confederate envoy. After Benjamin spent several days charming the Pollocks, the father prevailed upon the son to take Benjamin, writing that he "has no need to learn law, all he needs is to see something of the practice of our courts, and to obtain some introduction to the English Bar". ${ }^{23}$ Benjamin again employed Confederate links by choosing the Northern Circuit to practice; this included Liverpool where his knowledge of mercantile trade in American commodities was useful. As an anonymous American wrote "he seems properly to have joined the Northern Circuit, and the secessionist sympathizers at Liverpool ought to give him good business". ${ }^{124}$ The Law Reports indicate that this is what happened as Benjamin was soon representing firms involved in the cotton trade. ${ }^{125}$

Frustrated by what he regarded as the slow growth of his practice, Benjamin wrote a legal treatise to gain prominence at the bar. While this was not an uncommon endeavour, it was uncommon for one of his age and experience. And as one who began as a civil law lawyer Benjamin seemed an intellectual outsider. In his usual fashion, though, Benjamin turned what could be viewed as weakness into strength. The full title of his work was A Treatise on the Law of Sale of Personal Property; with References to the American Decisions and to the French Code and Civil Law. By explicitly incorporating the law and jurisprudence of these other jurisdictions Benjamin was able to meet the needs of a legal profession that was transforming its law from one formulated on procedure to one based on substance. ${ }^{126}$ Pollock thought that "one great and early advantage held by Benjamin as a lawyer" was his knowledge of the civil law, "the principles and practice of this great system of law Benjamin knew and appreciated thoroughly". ${ }^{127}$ But Benjamin was more than a civil lawyer for he already had a strong grasp of the common law. Not only had his years before the United States Supreme Court involved the common law, as was noted above it is clear that his commercial practice in New Orleans involved large elements of the common law in conjunction with civil law and civilian jurisprudence.

Benjamin's treatise was enormously successful and was received with near universal acclaim: "one of the most valuable legal publications of the year"128 and "entitled to rank in the highest class of text-books; and it is . . . one of the most important contributions to legal literature which has appeared for many years". ${ }^{129}$ The treatise succeeded because Benjamin went beyond a compendium of cases and provided a dominant conception of the law of sale, constructed upon principles as elucidated in the cases. It was the construction of law by principle, particularly principles common to the Romans and civilians, which was so attractive to readers. As Sheldon Amos observed, the difficulty with most of the treatises of the age was that by failing to go beyond cataloguing the cases and avoiding any attempt to show the cases as a part of a larger, rational system of law, the treatise writers produced work which paralysed

\footnotetext{
${ }^{123}$ Pollock, above, n 99, 397.

${ }^{124}$ Anon, (1866) 1 Am Law Review 220.

${ }^{125}$ See, for example, United States of America v Wagner (1867) LR 2 Ch App 582; In re Fraser, Trenholm, \& Co (1868) LR 4 Ch App 49; Thomson v Simpson (1870) LR 9 Eq 497; and Stringer v The English and Scottish Marine Insurance Company (1870) LR 5 QB 599.

${ }^{126}$ The same process can be seen in the work of an English contemporary: C MacMillan, "Stephen Martin Leake: A Victorian's View of the Common Law" (2011) 32 Journal of Legal History 3.

${ }^{127}$ Pollock, above, n 99, 398.

${ }^{128}$ The Law Times, 5 September, 1868, 350.

${ }^{129}$ The Solicitor's Journal and Reporter, 14 November, 1868, 28.
} 
the originality of the student and dulled the energy of the practitioner. ${ }^{130}$ By the end of Benjamin's career the treatise was regarded as the definitive work on the subject: "few works on English law have been so readily accepted and so universally used as "Benjamin on Sales"." 131

Benjamin's incorporation of civil law into his treatise was to have very real effects on the development of the common law. Although this occurred as a part of a larger transformation whereby treatise writers adopted, in piecemeal fashion, the jurisprudence of civilians as an analytical and structural framework for English contract law, it is clear that Benjamin's work had its own specific impact on the common law. Two such instances can be seen in the doctrine of mistake in contract law ${ }^{132}$ and the postal acceptance rules concerned with contractual formation at a distance. $^{133}$

While Benjamin lamented the rate at which his practice grew, his contemporaries observed that it expanded rapidly. ${ }^{134}$ What was the nature of this practice? While it might be thought that Benjamin would attract clients within the Jewish community, this does not appear to be the case. Indeed, Benjamin appears not to have had any active links within the Jewish community. ${ }^{135} \mathrm{He}$ was, in this regard, different from contemporary barristers, George Jessel and Arthur Cohen. Benjamin's clients came largely from the commercial community. The nature of his early practice is less clear than his later one. From 1870, however, one finds an increase in the Law Reports cases in which he appeared as counsel and from 1872 he appears with enormous regularity. ${ }^{136}$ In 1869 , Benjamin was made a Queen's Counsel of the County Palatine of Lancaster; the limitation seemingly made so as not to offend the United States. In 1872 Baron Hatherley once again advanced Benjamin's career when, impressed by arguments in Rankin v Potter, ${ }^{137}$ a marine insurance case, that Lord Hatherley conferred upon Benjamin a patent of precedence, taking rank over all future Queen's Counsel. The London Law Journal reported that the promotion "will be viewed with satisfaction by the whole profession". ${ }^{138}$

This advancement allowed Benjamin to specialise in appellate cases. The Law Reports indicate that Benjamin had come, in London, to specialise in the legal work which necessarily arose in the capital of a mercantile and trading empire. In this sense, the sort of law Benjamin was engaged was similar to that he had practised in New Orleans. We find him active in cases concerned with shipping, ${ }^{139}$ marine

\footnotetext{
${ }^{130} \mathrm{~S}$ Amos, Science of Jurisprudence, quoted in The Law Times, 15 June, 1872, 111.

${ }^{131}$ Pollock, above, n 99, 399. See, also, The Law Times, 17 February, 1883, 276 and 17 May 1884, 52; The Times, May 9, 1884, 10.

${ }^{132}$ C MacMillan, Mistakes in Contract Law (Hart, Oxford, 2010) 230-238.

${ }^{133}$ C MacMillan, "The Lousianan's Influence on British Law", in (ed) J Cairns, Louisiana in European Legal History (Traditio Iuris Romani, Glasgow, forthcoming).

${ }^{134}$ Pollock, above, n 99, 399; Selborne, above, n 111, 95.

${ }^{135}$ The Jewish Chronicle, 9 May 1884, 16.

136 The figures are impressive: 9 cases in 1872, 20 in 1873, 33 in 1874, 31 in 1875, 53 in 1876, 38 in 1877, 25 in 1878, 36 in 1879, 37 in 1880, 29 in 1881, 26 in 1882 and 4 in 1883.

137 (1873) LR 6 HL 83.

${ }^{138}$ Reprinted (1872-73) vol 7 Am Law Review 387.

${ }^{139}$ Chartered Mercantile Bank of India v Netherlands India Steam Navigation Company (1882) 9 QBD 118; Hopper v Burness (1876) 1 CPD 137; Dahl v Nelson, Donkin \& Co (1881) 6 App Cas 38 and Jackson v Union Marine Insurance Company (1874) LR 10 CP 125.
} 
insurance, ${ }^{140}$ admiralty matters, ${ }^{141}$ credit and financing, ${ }^{142}$ company law, ${ }^{143}$ bankruptcy, ${ }^{144}$ contract, ${ }^{145}$ and the sale of goods. ${ }^{146}$ Benjamin was, at times, involved in cases associated with landed interests, involving real property interests ${ }^{147}$ and succession. $^{148}$ A surprisingly large number of Benjamin's cases were significant ones: Cundy v Lindsay, ${ }^{149}$ The Franconia, ${ }^{150}$ and the case of the Titchborne claimant $^{151}$ are but a few examples.

Benjamin had an extensive practice before the Judicial Committee of the Privy Council and appeared in the lion's share of non-Indian Privy Council cases between 1877 and 1882. ${ }^{152}$ During that time he appeared in cases from colonies and Dominions which were to become Australia, Canada, New Zealand, South Africa, India, Malta, China, Turkey, the Channel Islands and the Isle of Man. Many of these areas were governed by a system of civil law and Benjamin's knowledge of civil law acted as an incentive to retain his services. Similarly, his knowledge of French and Spanish were important; he was retained in a large number of cases from Lower Canada where the governing law was civil law and the papers often in French.

\section{An Insider or an Outsider?}

As will be seen from this brief account, Benjamin was enormously successful in his endeavours. How, though did he transcend his origins on the margin of society - an impecunious, immigrant Jewish youth - to United States senator and successful Supreme Court counsellor? In answering this question, it is apparent that this success is attributable to Benjamin himself, a matter evident when he repeated this feat in transcending his status as political exile to the United Kingdom to the top of the bar. At the same time, though, it is worth observing that although Benjamin was, by various factors marginalised, at the same time he lived in an era when he had the basic attributes (he was male and white) in which he could participate in civic society in the United States and the United Kingdom. This was a necessary pre-condition for success, without which all personal attributes would be meaningless.

\footnotetext{
${ }^{140}$ Rivaz v Gerussi (1880) 6 QBD 222; Adamson v Newcastle Freight Insurance Association (1879) 4 QBD 462; Lohre v Aitchson (1877) 2 QBD 501; Inman Steampship Company v Bischoff (1882) 7 App Cas 670; and Rankin v Potter, above, n 126.

${ }^{141}$ Borjesson v Carlberg (1878) 3 App. Cas. 1316; The Onward (1873) LR 4 AE 38; and The M Moxham (1876) 1 PD 107.

${ }^{142}$ Horne v Rouquette (1878) 3 QBD 514; Swire v Redman (1876) 1 QBD 536; and National Bolivian Navigation Company v Wilson (1880) 5 App Cas 176.

143 Simm v Anglo-American Telegraph Company (1879) 5 QBD 188; Twycross v Grant (1877) 2 CPD 469; and Erlanger v New Sombrero Phosphate Company (1878) 3 App Cas 1218.

144 Glegg v Gilbey (1877) 2 QBD 209; Melhado v Watson (1877) 2 CPD 281; and Campbell v Im Thurn (1876) 1 CPD 267.

${ }^{145}$ Cundy v Lindsay (1878) 3 App Cas 459; Rhodes v Forwood (1876) 1 App Cas 256.

146 Johnson v Raylton (1881) 7 QBD 438; Borrowman v Drayton (1876) 2 Ex D 15; and Reuter v Sala (1879) 4 CPD 239

${ }^{147}$ Neill v Devonshire (1882) 8 App Cas 135; Gordon v Gordon (1882) 7 App Cas 713; and Davis v Treharne (1881) 6 App Cas 460.

148 Attorney General v Noyes (1881) 8 QBD 125; Swinton v Bailey (1878) 4 App Cas 70; and Taylor v Graham (1878) 3 App Cas 1287.

${ }^{149}$ (1878) 3 App Cas 459.

${ }^{150}$ (1876) LR 2 PD 8; (1878) LR 3 PD 164

${ }^{151}$ Castro v The Queen (1881) 6 App Cas 229.

${ }^{152} \mathrm{G}$ Wheeler, A Synopsis of all the Appeals Decided by the Judicial Committee from 1876 to 1891 (Stevens and Sons Limited: London 1893). Benjamin appeared in approximately 50 cases.
} 
What were the personal elements Benjamin deployed to enable him to transcend his status as an outsider? The first was undoubtedly his life-long ${ }^{153}$ capacity for hard work. Davis sought out Benjamin for the Confederate cabinet because "my acquaintance with Benjamin in the Senate had impressed me with the lucidity of his intellect, his systematic habits, and his capacity for labour". ${ }^{154}$ Pollock remarked about his English years that approached his tasks with the zeal and energy of a much younger man. ${ }^{155}$ It is also seems likely that a part of Benjamin's success was his ability to delegate work and to manage others in the conduct of a greater matter. To his capacity for industry was coupled great intellect. There seemed little that Benjamin could not master and his intellectual abilities were multi-faceted. Benjamin was practical and chose to practise in an area of which he had great knowledge mercantile trade. This was a knowledge acquired in boyhood and steadily built up: "few men had a sounder or wider range of knowledge an experience of the lawmerchant, including shipping, insurance and foreign trading, than Benjamin, long before he ever thought of leaving America". ${ }^{156}$

Industry, organisation and intellect were matched with exceptional oratorical abilities. As a barrister, he was thought to have "extraordinary powers as a dialectician". ${ }^{157} \mathrm{He}$ managed to adapt this skill to suit new conditions in England. ${ }^{158}$ Lord Selborne noted that, as an advocate, he "was quick, shrewd, and dexterous . . . Benjamin did not disdain any sort of argument which an honest man could use, but urged them all with equal courage". ${ }^{159}$ The strength of Benjamin's cases lay in the advancement of a number of grounds to reach the same conclusion. These arguments were based upon reason and worked from general principles, principles Benjamin based upon the cases.

Above all else, though, it was Benjamin's personal abilities that allowed him to succeed. It is clear that many with which he worked expressed anti-Jewish views and yet Benjamin ably withstood discriminatory treatment and prejudices. An example can be found in his client Prioleau whose letterbook reveals anti-Jewish sentiment and yet he was to represented by Benjamin. ${ }^{160}$ He was frequently described as a bon vivant, a great wit and an entertaining personality. His friend, Varina Davis, stated that Benjamin "seemed to have an electric sympathy with every mind with which he came into contact". 161 Lord Selborne described him as one whose "kindly unpretending manners made him a general favourite". ${ }^{162}$ Much of Benjamin's professional life was conducted against a backdrop of discord but he strove, as he explained, to always maintain "the most courteous manner" and that "I have

\footnotetext{
${ }^{153}$ Meade, above, n 4, 11 recounts from a classmate that little Judah did not play at recess but prepared himself for his upcoming lessons.

${ }^{154}$ J Davis, The Rise and Fall of the Confederate Government, vol. I (D. Appleton \& Co, New York, 1881) 242.

${ }^{155}$ Pollock, above, n 99, 399.

${ }^{156}$ Pollock, above, n 99, 399.

${ }^{157}$ Anon, A Generation of Judges by Their Reporter (Sampson Low, Marston, Searle \& Rivington, London, 1886) 198.

${ }^{158}$ Henry James advised him not to reveal that he considered the judges' knowledge of the law inferior to his own: Meade, above, n 4, 334-335.

${ }^{159}$ Selborne, above, n 111, 96.

${ }^{160}$ Letter to G Trenholm, 22 October, 1863 Business Records of Fraser, Trenholm \& Company, Merseyside Maritime Museum, Liverpool B/FT/Box 8/178.

${ }^{161}$ Letter to Francis Lawley, 8 June 1898, Lawley MSS Pierce Butler Papers 56-10-2, Louisiana Research Collection, Tulane University.

${ }^{162}$ Selborne, above, n 111, 96.
} 
endeavoured, upon all occasions, that my manner towards my brother Senators should be such that whilst we differ in opinion . . . there should be left no sting behind in the debates which might occur between us, that none but the kindliest and best feelings may exist". ${ }^{163}$ Benjamin's engaging manner and sociability acted to advance his interests and smoothing the path to his acceptance in a wide range of circles. An aspect of his personality was perseverance in the face of adversity.

Benjamin was able not only to overcome adversity, but also to turn what could be seen as weaknesses into strengths. Those factors that might have marginalised him were matters that he turned to his advantage. This is clearly seen in his passage into the English bar. He established himself through a combination of his Judaism and his Confederate support. He advanced his professional work in such a way as to take advantage of his civilian learning rather than to be inhibited by it. As can be seen in this brief biography, Benjamin cannot truly be described as an outsider. He was not marginalised from power, wealth or influence. That he was different from others was also the key to his success. If we compare Benjamin's fate to that of other Confederates the fact that he was an outsider, one who had a different world-view and different connections meant that he was able to withstand the collapse of the Confederacy and to begin anew. Judah Benjamin was to a great extent the master of his own destiny and not one marginalised by others.

${ }^{163}$ Above, n 76, 2824. 